\title{
Alteration in Metabolism of Acetylsalicylic Acid in Children with Down's Syndrome: Decreased Plasma Binding and Formation of Salicyluric Acid
}

\author{
M.S. EBADI ${ }^{[60]}$ and R. B. KugEL \\ Departments of Pharmacology and Pediatrics, University of Nebraska College of Medicine, \\ Omaha, Nebraska, USA
}

\begin{abstract}
Extract
This paper reports the differences in absorption and distribution in plasma of free and bound salicylate, and the differences in excretion of salicylic and salicyluric acid in the urine of children with Down's syndrome and in control subjects. After oral administration of a single dose of acetylsalicylic acid $(35 \mathrm{mg} / \mathrm{kg}$ ) to normal children, the peak level of salicylic acid in plasma occurred in $2 \mathrm{~h}$ and the drug level returned to the base line at approximately $8 \mathrm{~h}$; in children with Down's syndrome, the peak level of salicylic acid occurred in $4 \mathrm{~h}$ and the drug level returned to a base line at approximately $16 \mathrm{~h}$. In children with Down's syndrome, the 24-h excretion of salicylate metabolites in the urine indicated a higher level of free salicylic acid (table I) and a lower level of salicyluric acid (tables II and III) when compared with the control group. Although the concentration of salicylate is small in erythrocytes, children with Down's syndrome showed a higher level when compared with their normal counterpart (table IV). The in vitro plasma-binding studies indicated that in comparison with normal subjects, children with Down's syndrome were less capable of binding salicylate (table V).
\end{abstract}

\section{Speculation}

Patients with Down's syndrome are a highly abnormal group of individuals because of their morphological, physiological and biochemical aberrations. They are directed and influenced by their abnormalities, one manifestation of which is altered pharmacogenetics. It should be expected that any therapeutic regime must take these differences into consideration and dosage must be calculated not on the basis of body weight but according to the plasma level of the drug or of its active metabolites.

\section{Introduction}

Although no study has been conducted to determine the basic pharmacology of an agent in Down's syndrome, the available evidence suggests the presence of subnormal or abnormal physiological and biochemical functions in this condition. Biochemical data indi- cate that alterations occur in the activity of many enzymes $[2,3,9,10,18,25-27,34,39,41,48,50]$, in the level of some plasma electrolytes $[23,46]$, in the ratio of plasma proteins and hard tissue proteins $[1,5$, $13,19,36,40,42,45,47]$, and in the excretion of some intermediary metabolites $[19-22,33,35,51,53]$ in children with Down's syndrome. These children also 
demonstrate altered responses to hormones and pharmacological agents. Among the systems tested, abnormalities in response have been shown with glucose, insulin, and adrenalin tolerances [6], and with atropine [52]. Erythrocytic triiodothyronine uptake is extremely high in the presence of normal total body iodine [28].

The significance of these abnormalities is neither clear nor generally agreed upon; nevertheless, one might wonder to what extent the factors causing these abnormalities could also result in alteration of drugmetabolizing enzymes and drug metabolism in general.

As a model for the evaluation of drug metabolism in children with Down's syndrome, a pilot study was conducted with acetylsalicylic acid. This paper reports the results of studies of the absorption, distribution, half-life, and excretion of various metabolites of acetylsalicylic acid in these children and in control subjects.

Subjects

A group of 14 physically healthy and cytogenetically similar male and female children, between 5 and 6 years of age [54] having the karyotype of Down's syndrome with trisomy $G$, who were free from any medication, detectable disease; or major congenital anomalies were hospitalized on a research ward. Control subjects, matched for weight and age, were chosen from the Omaha Home for Children. In all instances human rights were safeguarded [55].

\section{Materials and Methods}

After a 48-h period of ward acclimatization, zero-hour fasting blood and urine samples were collected. Then, unbuffered acetylsalicylic acid (35 mg/kg) [56], crushed and preweighed, was suspended in a small amount of water and given orally followed by $200 \mathrm{ml}$ of water. Capillary blood was collected in heparinized test tubes at 15 and $30 \mathrm{~min}$, and 1, 2, 3, 4, 6, and $8 \mathrm{~h}$ after drug administration and, in subjects with Down's syndrome, up to $12-16 \mathrm{~h}$ or until the agent could no longer be detected in plasma.

Studies were begun at 8:00 AM in fasting subjects and breakfast was allowed after the drawing of the 1-h blood sample. Urines were collected as voided during the 24-h period of experimentation. The $\mathrm{pH}$ and the volume of the urines were determined and the samples were frozen at $-20^{\circ}$ without the addition of any preservatives; they were assayed within 2-3 days. Throughout the entire 3-day study period the children were fed a balanced diet that remained similar from day to day.

\section{Chemical Methods}

Salicylic acid in plasma was determined using the modified method of BRoDre et al. [12] and was modified to use less plasma. This method is specific for salicylic acid [12] and the normal constituents of plasma do not interfere to a measurable extent in the reactions. The total salicylates and salicyluric acid in urine were converted to free salicylic acid employing the method of BEDFORD et al. [4] and concentrations were expressed as equivalents of salicylic acid. The concentration of free salicylate in erythrocytes was determined and calculated according to the method of SMrrн et al. [44].

In vitro binding of salicylate. Blood for these studies was obtained by venipuncture and the heparinized plasma was used to determine the salicylate-binding capacity. The binding procedure, the dialyzing technique, the buffer $(0.14 \mathrm{M} \mathrm{NaCl}$ in $0.01 \mathrm{M}$ phosphate buffer adjusted to $\mathrm{pH} 7.4$ at $23^{\circ}$ ), and the method of calculation of the ultrafiltrate are those of DAvrs [17]. Quantities of sodium salicylate representing $1.0-5.0 \mathrm{mg} / \mathrm{ml}$ were added to $3 \mathrm{ml}$ of plasma; the plasma was placed in cellophane dialyzing tubing [57] and was suspended in $10 \mathrm{ml}$ of buffer. The dialysis was allowed to proceed for $24 \mathrm{~h}$. This interval had previously been shown by DAvis [17] to be sufficient for equilibration. The concentration of bound drug at each particular concentration of salicylate was calculated by subtracting the concentration of free salicylate (outside of the dialyzing tubes) from the concentration of bound and free (inside of the dialyzing tubes) and corrected for protein volume inside the tubes.

\section{Results}

\section{Free Salicylic Acid of Plasma}

After administration of a single dose of $35 \mathrm{mg} / \mathrm{kg}$, the drug was absorbed rapidly from the gastrointestinal tract since it could be detected in plasma in both groups 15 min after drug administration. The groups varied, however, in that in normal children, the peak salicylic acid level in plasma occurred at $2 \mathrm{~h}$ and returned to the base line at approximately $8 \mathrm{~h}$ whereas in children with Down's syndrome, the peak level of salicylic acid in plasma occurred at $4 \mathrm{~h}$ and returned to the base line at approximately $16 \mathrm{~h}$ (table IV).

\section{Urinary Metabolites}

The results demonstrated that in a 24-h period children with Down's syndrome excreted $48.0 \%$ of the drug as salicylic acid compared with $30.5 \%$ excreted by the control subjects (table I). On the other hand, they excreted $30.2 \%$ as salicyluric acid compared with $51.0 \%$ excreted by the control subjects in $24 \mathrm{~h}$ (tables II and III). 
Table I. Excretion of salicylic acid in urine after oral administration $(35 \mathrm{mg} / \mathrm{kg})$ of acetylsalicylic acid

\begin{tabular}{lcc}
\hline \multirow{2}{*}{$\begin{array}{l}\text { Time of urine } \\
\text { collection after } \\
\text { drug administra- } \\
\text { tion, } \mathrm{h}\end{array}$} & \multicolumn{2}{c}{ Salicylic acid excretion, $\mathrm{mg} / \mathrm{h}^{1}$} \\
\cline { 2 - 3 } & $\mathrm{Nown}=14$ & $\mathrm{~N}=14$ \\
\hline 0 & 0 & 0 \\
2 & $12.0 \pm 0.85^{3}$ & $11.5 \pm 0.77^{3}$ \\
3 & $40.0 \pm 1.20$ & $37.0 \pm 1.38$ \\
5 & $45.0 \pm 1.80$ & $37.0 \pm 1.35$ \\
7 & $52.0 \pm 1.75$ & $28.0 \pm 1.48$ \\
10 & $38.0 \pm 1.25$ & $18.0 \pm 1.24$ \\
14 & $32.0 \pm 1.00$ & $15.0 \pm 0.98$ \\
20 & $28.0 \pm 1.20$ & $14.0 \pm 1.20$ \\
22 & $24.0 \pm 1.30$ & $8.0 \pm 1.00$ \\
24 & $20.0 \pm 1.20$ & $4.0 \pm 0.68$ \\
Acetylsalicylic acid & & \\
excreted as salicylic & & \\
acid in $24 \mathrm{~h}, \%$ & 48.0 & 30.5 \\
\hline
\end{tabular}

1 The values represent an average of urine salicylate obtained during the time interval listed. The increase in salicylate acid excretion was greater in Down's syndrome patients at $P<0.05$.

${ }^{2}$ Normal subjects and those exhibiting Down's syndrome were 5-6 years of age.

${ }^{3}$ Mean \pm SEM.
Table II. Rates of excretion of salicyluric acid in the urine after oral administration $(35 \mathrm{mg} / \mathrm{kg})$ of acetylsalicylic acid

\begin{tabular}{lcc} 
& \multicolumn{3}{c}{ Time of urine } \\
collection after & \multicolumn{2}{c}{ Salicyluric acid, $\mathrm{mg} / \mathrm{h}^{\mathbf{1}}$} \\
\cline { 2 - 3 } $\begin{array}{l}\text { drug administra- } \\
\text { tion, } \mathrm{h}\end{array}$ & $\mathrm{Down}$ 's syndrome & $\mathrm{Normal}^{2,3}$ \\
$\mathrm{~N}=14$ & $\mathrm{~N}=14$ \\
\hline 2 & $7.0 \pm 0.65^{4}$ & $10.0 \pm 0.75^{4}$ \\
3 & $25.0 \pm 1.20$ & $60.9 \pm 2.25$ \\
5 & $28.1 \pm 1.80$ & $65.8 \pm 3.35$ \\
7 & $32.4 \pm 1.27$ & $60.6 \pm 4.08$ \\
10 & $22.4 \pm 1.41$ & $50.4 \pm 5.02$ \\
14 & $20.0 \pm 1.15$ & $26.2 \pm 3.80$ \\
20 & $17.5 \pm 1.05$ & $20.2 \pm 2.25$ \\
22 & $15.0 \pm 0.95$ & $18.0 \pm 2.00$ \\
24 & $13.0 \pm 1.08$ & $8.0 \pm 1.00$ \\
Acetylsalicylic acid & & \\
excreted as salicyluric & & \\
acid in $24 \mathrm{~h}, \%$ & 30.2 & 51.0 \\
\hline
\end{tabular}

1 Salicyluric acid concentration is expressed as equivalent of salicylic acid.

${ }^{2}$ Normal subjects and those exhibiting Down's syndrome were $5-6$ years of age.

${ }^{3}$ The salicyluric acid excretion was greater in the normal children at $P<0.05$.

${ }^{4}$ Mean \pm SEM.

Table III. Excretion of salicylic acid and salicyluric acid in the urine after oral administration ( $35 \mathrm{mg} / \mathrm{kg})$ of acetylsalicylic acid

\begin{tabular}{|c|c|c|c|c|c|}
\hline \multirow[t]{2}{*}{ Subjects } & \multirow[t]{2}{*}{ Age } & \multirow[t]{2}{*}{ Sex } & \multirow{2}{*}{$\begin{array}{l}\text { Avg wt } \\
\text { kg }\end{array}$} & Salicylic acid, $\%^{1}$ & Salicyluric acid, $\%^{1}$ \\
\hline & & & & \multicolumn{2}{|c|}{ Range } \\
\hline \multirow[t]{5}{*}{ Down's syndrome } & 5 & $\mathbf{M}$ & 17.2 & $43.3-55.5^{2}$ & $25.4-34.6^{2}$ \\
\hline & 5 & $F$ & 18.7 & $41.7-48.8$ & $25.0-31.2$ \\
\hline & 6 & $\mathrm{M}$ & 20.2 & $45.0-56.6$ & $28.8-36.0$ \\
\hline & 6 & $\mathrm{M}$ & 18.8 & $41.4-48.8$ & $25.1-28.9$ \\
\hline & & & & Mean $=48.0$ & Mean $=30.2$ \\
\hline \multirow[t]{5}{*}{ Normal } & 5 & M & 18.5 & $26.7-34.5$ & $45.5-64.1$ \\
\hline & 5 & $\mathrm{~F}$ & 16.2 & $26.9-35.6$ & $40.1-61.3$ \\
\hline & 6 & M & 19.2 & $25.7-34.6$ & $49.1-60.0$ \\
\hline & 6 & $\mathrm{~F}$ & 17.3 & $22.6-32.6$ & $38.1-47.8$ \\
\hline & & & & Mean $=30.5$ & Mean $=51.0$ \\
\hline
\end{tabular}

1 The concentration of salicyluric acid is expressed as the equivalent of salicylic acid. The difference in salicylic acid excretion between the normal subjects and those with Down's syndrome was significant $(P<0.05)$.

2 The values represent the percentage of acetylsalicylic acid excreted as each metabolite in $24 \mathrm{~h}$. 
Table IV. Salicylic acid in plasma and erythrocytes after oral administration $(35 \mathrm{mg} / \mathrm{kg})$ of acetylsalicylic acid

\begin{tabular}{lcccc}
\hline \multirow{2}{*}{$\begin{array}{l}\text { Time after drug } \\
\text { administration, }\end{array}$} & \multicolumn{3}{c}{ Salicylic acid, $\mathrm{mg} / 100 \mathrm{ml}$ of plasma or packed RBC } \\
\cline { 2 - 5 } $\mathrm{h}$ & \multicolumn{2}{c}{ Plasma } & & \multicolumn{2}{c}{ Erythrocytes } \\
\cline { 2 - 5 } \cline { 2 - 5 } & Down's syndrome & Normal & Down's syndrome & Normal \\
\hline 0 & 0.00 & 0.00 & 0.00 & 0.00 \\
0.25 & $0.72 \pm 0.08^{1}$ & $0.80 \pm 0.061$ & $0.05 \pm 0.061$ & $0.07 \pm 0.09^{1}$ \\
0.5 & $1.65 \pm 0.12$ & $1.50 \pm 0.16$ & $0.30 \pm 0.09$ & $0.20 \pm 0.11$ \\
1 & $2.00 \pm 0.17$ & $2.85 \pm 0.19$ & $0.30 \pm 0.14$ & $0.31 \pm 0.08$ \\
2 & $3.70 \pm 0.28$ & $4.35 \pm 0.35$ & $0.52 \pm 0.12$ & $0.48 \pm 0.08$ \\
3 & $4.20 \pm 0.35$ & $4.00 \pm 0.41$ & $0.65 \pm 0.15$ & $0.45 \pm 0.09$ \\
4 & $7.70 \pm 0.48$ & $3.44 \pm 0.35$ & $1.05 \pm 0.11$ & $0.35 \pm 0.10$ \\
6 & $6.20 \pm 0.40$ & $1.45 \pm 0.18$ & $0.98 \pm 0.10$ & $0.18 \pm 0.12$ \\
8 & $4.95 \pm 0.40$ & $0.65 \pm 0.09$ & $0.90 \pm 0.12$ & $0.07 \pm 0.09$ \\
10 & $3.90 \pm 0.27$ & $0.12 \pm 0.02$ & $0.75 \pm 0.08$ & - \\
12 & $2.89 \pm 0.18$ & - & $0.65 \pm 0.09$ & - \\
14 & $1.80 \pm 0.16$ & - & $0.44 \pm 0.08$ & - \\
16 & $1.00 \pm 0.14$ & - & $0.45 \pm 0.10$ & - \\
\hline
\end{tabular}

1 Mean \pm sEM.

Concentration of Salicylate in Erythrocytes

The erythrocyte membrane is freely permeable to the ultrafiltrate portion of the plasma salicylates and the drug is not bound by the protein of erythrocytes [43]. Although the concentration of salicylate in the erythrocytes was small, the children with Down's syndrome showed a higher level of salicylate, which corresponded to higher plasma levels, compared with the control group (table IV).

The In Vitro Binding of Salicylate

The results of in vitro plasma binding of salicylate is shown in table $\mathrm{V}$. The percentage of salicylate binding decreased as the concentration of salicylate increased. Children with Down's syndrome demonstrated a lower ability to bind salicylate compared with the control group.

\section{Urinary $p H$ and Volume Evaluation}

There was no statistically significant difference in the mean $\mathrm{pH}$ value or volumes of the entire urine collection of the two groups studied for $24 \mathrm{~h}$.

\section{Discussion}

Orally ingested acetylsalicylic acid is absorbed rapidly from the stomach and the upper part of the small intestine. Absorption occurs predominantly by passive diffusion of acetylsalicylic acid across gastrointestinal membranes. The concentration of nonionized drug and the $\mathrm{pH}$ of the mucosal surface (low $\mathrm{pH}$ of gastric juice enhances while high $\mathrm{pH}$ impedes absorption) influences absorption [15]. The absorbed acetylsalicylic acid is rapidly hydrolyzed by a plasma esterase to salicylic acid. As much as $30 \%$ of an orally administered dose of acetylsalicylic acid has been found to be present in the plasma unaltered at $30 \mathrm{~min}$, with almost no detectable level at $2 \mathrm{~h}[29,32]$. At the therapeutic plasma concentration, from 60 to $80 \%$ of the salicylate in human plasma is bound to plasma proteins, especially albumin [37]. Binding takes place

Table V. In vitro binding of sodium salicylate to plasma

\begin{tabular}{cccc}
\hline \multicolumn{2}{c}{ Down's syndrome } & \multicolumn{2}{c}{ Normal } \\
\cline { 4 - 4 } Plasma $^{1}$ & $\begin{array}{c}\text { Ultrafiltrate } \\
\text { mg salicylate } / \mathrm{ml}\end{array}$ & $\begin{array}{c}\text { Plasma } \\
\text { ( }\end{array}$ & Ultrafiltrate \\
\hline 1.0 & 0.013 & 1.0 & 0.050 \\
2.0 & 0.038 & 2.0 & 0.095 \\
3.0 & 0.075 & 3.0 & 0.200 \\
4.0 & 0.155 & 4.0 & 0.250 \\
5.0 & 0.200 & 5.0 & 0.300 \\
\hline
\end{tabular}

1 From $1.0-5.0 \mathrm{mg} / \mathrm{ml}$ of salicylate were added to $3 \mathrm{ml}$ of plasma before incubation at $37^{\circ}$ and dialysis in $\mathrm{NaCl}$ phosphate buffer, $\mathrm{pH} 7.4$, at $23^{\circ}$ for $24 \mathrm{~h}$. 
through free carboxyl groups and the 0 -phenolic group enhances the affinity for protein [45]. Aspirin itself is not bound to plasma protein [16].

The children with Down's syndrome demonstrated lower bound (table V) and higher free salicylate (table IV) than the control group. One explanation for this may be the presence of hypoalbuminemia $[5,19,36$, $45,47]$ that results in decreased binding of free salicylic acid. Peak levels of salicylic acid were reached in $4 \mathrm{~h}$ in children with Down's syndrome compared with the 2-h period necessary for attainment of peak levels in normal children. Since all children were fasted at the time of drug administration, the contents of the stomach could have no effect. The delay in absorption of salicylate could be in part related to decreased plasma protein binding in the children with Down's syndrome. The accumulation of free salicylate in the circulation could retard the esterase activity and the total acetylsalicylic acid could be temporarily higher, which in turn might reduce passive diffusion from the intestinal tract into the children's circulation.

Similarly, the delay in excretion of salicylate could also relate to decreased protein binding. Salicylate not bound to albumin might have a volume of distribution much greater than in the instances where normal binding had taken place. Thus, more salicylate would be within intracellular fluid and would not be available for either conjugation or ultrafiltration at the level of kidney, on the assumption that transport occurs via protein binding. This mechanism could contribute then to both delayed conjugation and excretion of salicylic acid. This reasoning is in keeping with studies reporting the results obtained with high [49] and low [11] plasma salicylate levels.

The erythrocyte membrane is freely permeable to the ultrafiltrate portion of the plasma salicylate and the drug is not bound by the protein of the erythrocytes [43]. Children with Down's syndrome demonstrated higher erythrocyte levels of salicylate that corresponded to the higher plasma level of the drug.

The major route of salicylate elimination is by metabolism to salicyluric acid. Thus, the rate of excretion of salicyluric acid closely corresponds to the rate of formation [31]. Children with Down's syndrome excreted significantly less salicyluric acid with correspondingly larger amounts of free salicylic acid, compared with normal subjects (table II). The $\mathrm{pH}$ of the urine affects markedly the excretion of salicylates. The kidneys excrete less salicylate when the urine is acidic and more when the urine is basic. Since the $\mathrm{pH}$ of the urine of both groups remained the same throughout the period of study, changes in urine $\mathrm{pH}$ could not have had any major influence on the excretion of free salicylic acid or the formation of salicyluric acid.

Decreased salicyluric acid formation might also be explained by a decrease in the activity of hepatic enzymes that conjugate glycine with salicylic acid to form salicyluric acid [14]. Since children with Down's syndrome have some degree of liver impairment [38], abnormalities in drug-metabolizing enzymes would not be surprising. This is consistent with the observation made by Gershofr et al. [21] that children with Down's syndrome were unable to methylate some compounds at normal rates.

Oral administration of $p$-aminobenzoic acid increases plasma level of salicylate. It has also been shown that $p$-aminobenzoic acid interferes with the formation of salicyluric acid and hippuric acid. This observation suggests that the enzyme system that conjugates glycine and salicylic acid or benzoic acid may be the same [43]. To test the hypothesis of subnormality in the activity of the enzyme conjugating glycine and salicylic acid, measurement of hippuric acid after a benzoic acid load was undertaken. Preliminary observations demonstrated that subjects with Down's syndrome excreted less hippuric acid after benzoic acid loading than did normal subjects. The decreased hippuric acid formation supports the view that hepatic function is abnormal in patients with Down's syndrome.

\section{Summary}

Children with Down's syndrome exhibit increased levels of free, and decreased levels of bound salicylic acid in the plasma, increased excretion of free salicylic acid, and decreased excretion of salicyluric acid in the urine. Preliminary evidence is presented that conjugation with glycine may in part explain the observations.

\section{References and Notes}

1. Allerhand, J.; Karelitz, S.; Isenberg, HD.; Penbharkxul, S. and Ramos, A.: The lacrimal proteins in Down's syndrome (mongolism). J. Pediat. 62: 235 (1963).

2. Alter, A.A.; Lee, S.L.; Pourfar, M. and DubKIN, G.: Studies of leukocyte alkaline phosphatase in mongoloids: A possible chromosome marker. Blood 22: 165 (1963).

3. Baike, A. G.; Lorder, P. B.; Degruchy, G. C. and Prr, D. B.: Phosphohexokinase activity of erythrocytes in mongolism: Another possible marker of chromosome 21. Lancet $i$ : 412 (1965).

4. Bedford, C.; Cummings, A.J. and Martin, B. K.: A kinetic study of the elimination of salicylate in man. Brit. J. Pharmacol. 24: 418 (1965).

5. BENDA, C.E.: The child with mongolism; p. 276 
(Grune and Stratton, New York 1960).

6. Benda, C. E.: Mongolism and cretinism; 2nd ed., rev., p.316 (Grune and Stratton, New York 1949).

7. Berman, J.L.; Hulten, M. and Lindsten, J.: Blood serotonin in Down's syndrome. Lancet $i$ : 730 (1967).

8. Berman, J. L.; Justice, P. and Hsia, D.Y.Y.: The metabolism of $5 \mathrm{HT}$ (serotonin) in the newborn. J.Pediat. 67: 603 (1965).

9. Beutler, E.; Goldenburg, E.W.; Ohno, S. and Yetrra, M.: Chromosome-21 and paroxysmal nocturnal hemoglobinuria. Blood 24: 160 (1964).

10. Brandt, N.J.; Frøland, A.; Mikkelsen, M.; Nielsen, A. and Tolstrup, N.: Galactosemia locus and the Down's syndrome chromosome. Lancet $i i$ : 700 (1963).

11. Brodie, B. B.; Burn, J.J. and Weiner, M. : Metabolism of drugs in subjects with Haenne's cirrhosis. Med.exp. 1: 290 (1959).

12. Brodie, B. B.; Udenfriend, S. and Goburn, A. F.: The determination of salicylic acid in plasma. $J$. Pharmacol. exp.Ther. 80: 114 (1944).

13. Garver, M.J.; Wiltse, H. and Wittson, C.L.: Basic studies in mongolism. I. Serum proteins. Dis. nerv. Syst. 20: 162 (1959).

14. Cohen, P.P. and MaGrlvery, R.W.: Peptide bond synthesis. III. On the mechanism of $p$-aminohippuric acid synthesis. J.biol. Chem. 171: 121 (1947).

15. Gummings, A.J.; Martin, B.K. and Renton, R.: The elimination of salicylic acid in man: Serum concentrations and urinary excretion rates. Brit. J.Pharmacol. 26: 461 (1966).

16. Davidson, C. and Smith, P.K.: The binding of salicylic acid and related substances to purified proteins. J. Pharmacol. exp.Ther. 133: 161 (1961).

17. DAvis, B. D. : The binding of sulfonamide drugs by plasma proteins. A factor in determining the distribution of drugs in the body. J. clin. Invest. 22: 753 (1965).

18. Donnell, G.N.; NG, N.G.; Bergren, W.R.; Melnyk, J. and Koch, R.: Enhancement of erythrocyte galactokinase activity in Langdon-Down's trisomy. Lancet $i$ : 553 (1965).

19. Donner, M.: Study of immunology and biology of mongolism. Ann.med. exp. fenn. Suppl. 32: 80 (1954).

20. Fuller, R.N.; Luce, M.W. and Mertz, E.T.: Serum uric acid in mongolism. Science 137: 868 (1962).

21. Gershoff, S.N.; Hegsted, D.M. and Trulson, M.E.: Metabolic studies in mongolism. Amer.J. clin. Nutr. 6: 526 (1958).

22. Gershoff, S.N.; MAYer, A.L. and Kulczcki, L. L.: Effect of pyridoxine administration on the urinary excretion of oxalic acid, pyridoxine and related compounds in mongoloids and non-mongoloids. Amer. J. clin. Nutr. 7: 76 (1959).

23. Gofman, J.W.: Chemical elements of blood of man II (CB). Levels of sixty-six chemical elements in Down's disease (mongolism). Univ. Calif. Radiat. Lab. 10211: 69 (1962).

24. Goldstein, H.: A study of mongolism and nonmongoloid mental retardation in children. Arch. Pediat. 71: 11 (1954).

25. Hsia, D.Y.Y.; Inouye, T.; Wong, P. and South, A.: Studies on galactose oxidation in Down's syndrome. New Engl.J. Med. 270: 1085 (1964).

26. KrnG, M.J.; Grulis, E. M. and Barkre, A. G. : Alkaline phosphatase activity in polymorphs in mongolism. Lancet $i i: 1302$ (1962).

27. Krone, H.; Wolf, V.; Goedde, H.W. and BAITSCH, H. : Enhancement of erythrocyte galactokinase activity in Langdon-Down's trisomy. Lancet ii: 590 (1964).

28. Kurland, G.S.; Fishman, J.; Hamolsky, M.W. and FreEDBerG, A. S. : Radioisotopics study of thyroid function in 21 mongoloid subjects. J.clin. Endocrin. 17: 552 (1957).

29. Lester, D.; Lolli, G. and Greenberg, L. A. : The fate of acetylsalicylic acid. J. Pharmacol. exp.Ther. 87: 329 (1946).

30. Levinson, A. and Goldenberg, C.: Mental retardation in children. J.Amer. med. Ass. 152: 781 (1953).

31. Levy, G.: Salicylurate formation demonstration of Michaelis-Menten kinetics in man. J.pharm. Sci. 54: 496 (1965).

32. Mandel, H.G.; Cambosos, N.M. and Smith, P.K.: The presence of aspirin in human plasma after oral administration. J.Pharmacol. exp.Ther. 112: 495 (1954).

33. MaCoy, E.E.; Anast, C.S. and Naylor, J.J.: The excretion of oxalic acid following deoxypyridine and tryptophan administration in mongoloid and non-mongoloid subjects. J.Pediat. 65: 208 (1964).

34. Mellman, W.J.; Oski, F.A.; Maciera-Coelho, A. and HARris, H. : Leukocyte enzymes in Down's syndrome. Lancet $i i: 674$ (1964).

35. Mertz, E.T.; Fuller, R.W. and Congorn, J. M.: Serum uric acid in young mongoloids. Science 141 : 535 (1963).

36. Nelson, T.L.: Serum protein and lipoprotein fraction in mongolism. Amer. J. Dis. Child. 102: 369 (1961).

37. Reynolds, R. G. and GLufF, L.E.: Interaction of serum and sodium salicylate: Changes during acute infection and its influence on pharmacological activity. Bull.Johns Hopk. Hosp. 107: 278 (1960). 
38. Roosen-Runge, E. C.: Fatty infiltration of the liver in patients with mongolism and in children with hydrocephaly and microcephaly. Amer. J. Path. 23: 79 (1947).

39. Rosner, F.; Ong, B.H.; Paine, R.S. and MahaNAMD, D.: Biochemical differentiation of trisomic Down's syndrome from that due to translocation. New Engl.J. Med. 273: 1356 (1965).

40. Shanse, B. and Laurell, C. B.: The immune globulins in mongolism. Acta med.scand. 172: 63 (1962).

41. Shih, L.Y.; Wong, P.; INouye, T.; MakleR, M. and Hsia, D.Y.Y.: Enzymes in Down's syndrome. Lancet $i i: 746$ (1965).

42. Simon, A.; Ludwig, G.; Gofman, J.W. and Grook, G.H.: Metabolic studies in mongolism: Serum protein bound iodine, cholesterol and lipoprotein. Amer. J. Psychiat. III: 139 (1954).

43. Sмiтh, P. K.: Gertain aspects of the pharmacology of the salicylates. Pharmacol. Rev. 1: 353 (1949).

44. Smrth, P.K.; Gleason, H.L.; Stoll, G.G. and Ogorzalek, S.: Studies on the pharmacology of salicylates. J. Pharmacol. exp.Ther. 87: 237 (1946).

45. Sobel, A.E.: Vitamin A absorption and other blood composition studies in mongolism. Amer.J. ment. Defic. Res. 62: 642 (1958).

46. Stern, J. and Lewis, W.H.P.: Calcium, phosphate and phosphatase in mongolism. J.ment. Sci. 104: 880 (1958).

47. Stern, J. and Lewrs, W.H.P.: Serum proteins in mongolism. J.ment. Sci. 103: 222 (1957).

48. Stern, J. and Lewis, W.H.P.: Serum esterase in mongolism. J.ment. Defic. Res. 6: 13 (1962).

49. SwinToskx, J.V.: Illustration and pharmaceutical interpretation of first order drug elimination rate from the blood stream. J.Amer. pharm. Ass. 45: 395 (1956).

50. Trubowitz, S.; Kirkman, D. and Masek, B.: Leukocyte alkaline phosphotase in mongolism. Lancet ii: 486 (1962).
51. Tu, J. and ZelLweger, H.: Blood serotonin in Down's syndrome. Lancet ii: 715 (1965).

52. WorTrs, J. and JACKIM, E.: Metabolic studies in mongolism; in: Recent advances in biological psychiatry, vol.3, p.185 (Grune and Stratton, New York 1961).

53. WRIGHT, S.W. and FinK, K.: Excretion of betaaminobutyric acid in normal, mongoloid and nonmongoloid mentally defective children. Amer.J. ment. Defic. 61: 530 (1957).

54. The children were selected from the Beatrice State Home for the Mentally Defective, Beatrice, Nebraska.

55. All procedures were performed in accordance with the provisions set forth in the Declaration of Helsinki.

56. Salicyluric used for standard was provided by A.H. Robins Company, Inc., Richmond, VA.

57. Dialyzing tubing was manufactured by Union Carbide Corporation, Chicago, IL.

58. The authors gratefully acknowledge the help of Dr. James Eisen, Director of the Section of Human Genetics, for supplying karyotype data; the excellent cooperation of the personnel of the Beatrice State Hospital, especially Mr. M.E.Wyant, Mr. A. E.MaElravy, and Mrs. G. Ottersberg; and appreciation to the personnel of the mental retardation research ward, especially Drs. S. Hussain and M.Patney, and Mrs. G. Eyberg, Mrs. D. BOWER, and Mrs. L. Miller. The technical assistance of Mrs. M.Johnson and Miss S. SchindLeR is similarly acknowledged.

59. Supported by National Institute of Child Health and Human Development Grant no.HD-00370.

60. Requests for reprints should be addressed to: Manuchatr S. Ebadi, Ph.D., Laboratory of Preclinical Pharmacology, National Institute of Mental Health, William A.White Building, St. Elizabeth's Hospital, Washington, DG 20032 (USA).

61. Accepted for publication October 3, 1969. 